\title{
The Effect of Exogenous Proline Application on Cotton Plant (Gossypium hirsutum L.) Under Drought Stress on Some Physiological Parameters
}

\author{
Nimet KILINÇOĞLU1* ${ }^{*}$ Cevher İlhan CEVHERİ², Abdulcenap CEVHERİ1 ${ }^{1}$, Hatice Yüsra NAHYA ${ }^{1}$ \\ ${ }^{1}$ Harran University, Faculty of Science $\mathcal{E}$ Art, Deparment of Biology, Şanluurfa, Turkey \\ ${ }^{2}$ Harran University, Deparment of Landscape and Ornamental Plants Vocational School of Technical Sciences, Şanluurfa, Turkey \\ ORCID ID: Nimet Kılınçoğlu: https://orcid.org/0000-0001-7935-9216; Cevher İlhan Cevheri: https://orcid.org/0000-0002-7070-2652; \\ Abdulcenap Cevheri: https://orcid.org/0000-0002-3759-4645; Hatice Yüsra Nahya: https://orcid.org/0000-0003-2228-5118
}

\begin{abstract}
Received: 20.08.2020 Accepted: 02.11.2020 Published online: 13.11.2020 Issue published: 31.12 .2020
Abstract: Plants are exposed to many stresses such as drought stress. In our study, PEG 6000 solution was used and 3 drought levels were created $\left(0 \%, 10 \%, 20 \% \mathrm{~g} \mathrm{~L}^{-1}\right)$. These drought groups were also divided into 2 subgroups by applying 0 (control: no proline solution) and $2 \mathrm{mM}$ proline solution. It was aimed to see the damages caused by different drought levels in the cotton plant and to see how much the exogenous proline application remedy this damage. The trial pattern was made in pots with 3 repetitions, the trial was set up in the air conditioning room twice. The changes in the values of chlorophyll a and $b$, carotenoid, total dissolved protein, total dissolved carbohydrate and some nutritional elements in the stress and control groups were examined. Chlorophyll a and $b$ decreased due to the increasing drought dose; increased carotenoid, total dissolved protein and carbohydrate; It was observed that the $\mathrm{K}$ element increased, $\mathrm{Ca}, \mathrm{Mg}, \mathrm{Na}$ and $\mathrm{P}$ element decreased. However, it was observed that the negative effects of drought stress in cotton plants were reduced with proline application.
\end{abstract}

Keywords: Chlorophyll, protein, carbohydrate, nutrional elements.

\section{Kuraklık Stresi Altındaki Pamuk Bitkisine (Gossypium hirsutum L.) Dışsal Prolin Uygulamasının Bazı Fizyolojik Parametreler Üzerindeki Etkisi}

Öz: Bitkiler kuraklık stresi gibi birçok strese maruz kalmaktadırlar. Araştırmamızda PEG 6000 çözeltisi kullanılmış, 3 adet kuraklık seviyesi oluşturulmuştur $\left(\% 0, \% 10, \% 20 \mathrm{~g} \mathrm{~L}^{-1}\right)$. Bu oluşturulan kuraklık grupları da kendi içinde 0 (kontrol: prolin çözeltisi uygulanmamış) ve $2 \mathrm{mM}$ prolin çözeltisi uygulanarak iki alt gruba ayrılmıştır. Pamuk bitkisinde farklı kuraklık seviyelerinin oluşturduğu zararlanmaları görüp, dışsal prolin uygulamasının bu zararlanmayı ne kadar iyileştirdiğini görmek amaçlanmıştır. Deneme deseni, saksılarda üç tekrarlamalı olarak yapılmıştır ve deneme deseni iklimlendirme odasında iki kez kurulmuştur. Stres ve kontrol gruplarında klorofil a ve b, karotenoid, toplam çözünmüş protein, toplam çözünmüş karbonhidrat ve bazı besin elementlerinin değerlerinin değişimi incelenmiştir. Artan kuraklık dozuna bağlı olarak klorofil a ve b'nin azaldığı; karotenoidin, toplam çözünmüş protein ve karbonhidratın arttığı; K elementinin arttığı, Ca Mg, Na ve P elementinin azaldığı görülmüştür. Bununla birlikte prolin uygulamasıyla pamuk bitkisindeki kuraklık stresinin olumsuz etkilerinin azaldığı gözlenmiştir.

Anahtar kelimeler: Klorofil, protein, karbonhidrat, besin elementleri.

\section{Giriş}

Pamuk, lifleri ile tekstil sanayisinin; çiğidi ile yă sanayisinin; küspesi ile yem sanayisinin önemli bir hammaddesidir. Ayrıca pamuk çiğidinin üzerindeki kısa lifler (Linter) barut, dolgu ve boya sanayisinin önemli bir hammaddesidir. Pamuk lifi dünya ticaretinin ve tekstil sanayisinin önemli hammaddesidir (Grimes \& El Zik, 1990). Ülkemiz ihracatının \%35'i tekstil sanayisine ait olduğunu düşünürsek, pamuğun stratejik bir ürün olduğu ortaya çıkmaktadır. Dünyada pamuk lifi üretimi en çok Hindistan'da üretilmektedir. Hindistan'1 sırayla Çin, ABD ve Brezilya izlemektedir. Türkiye yıllık yaklaşık 827 bin ton lif pamuk üretimiyle dünya pamuk üretiminde altıncı sırada yer almaktadır (Atasoy, 2013; Peynircioğlu, 2014).

2019/20 sezonunda dünya genelinde pamuk üretiminde Hindistan (\%24.4), Çin (\%22.2), ABD (\%17.4), Pakistan(\%6.1), Brezilya(\%9.3), Türkiye (\%3.3) yer almıştır (USDA, 2019). 2019/20 sezonunda Türkiye'de pamuk üretimi 814 bin ton lif pamuğa denk gelen 2.2 milyon ton kütlü pamuk üretimi gerçekleşmiş, pamuk lif verim değeri $187 \mathrm{~kg} /$ da olmuştur. Türkiye'de pamuk üretimin \%88'ini
Şanlıurfa, Aydın, Hatay, Diyarbakır, Adana ve İzmir gibi iller karşılamaktadır. Şanlıurfa ili tek başına bu oranın \%42'sini karşılamaktadır (Özüdoğru, 2019).

Kuraklık; dünya genelinde ürün verimliliğini düşüren, bitki gelişimini önemli ölçüde kısıtlayan abiyotik stres faktörlerinin başında gelmektedir (Mirjahanmardi \& Ehsanzadeh, 2016; Zali \& Ehsanzadeh, 2018). Dünyanın ekili alanlarından yaklaşık \%45'i kuraklık stresine maruz kalmaktadır ve dünya genelinin kurak ve kuraklığa yakın yerlerde yaşayan nüfusun \%38'inin gida güvenliğini önemli ölçüde etkilemektedir (Zali \& Ehsanzadeh, 2018). Şanlıurfa ilinde iklim, yazları sıcak ve kurak geçerken kışları da kurak geçmektedir (Taş \& Kırnak, 2011). Polietilen glikol (PEG) gibi maddeler kullanılarak kuraklık stresi laboratuvar koşullarında oluşturulabilmektedir. Molekül ağırlığı yüksek olan PEG, kimyasal bir madde olduğundan ortamdaki su miktarını düzenleyerek istenilen seviyede kuraklık oluşturmaya yardımcı olur. PEG, bitkiler tarafından alınmayıp, hiçbir toksisite etkisi göstermeyen bir maddedir ve zamanla bulunduğu çözelti içindeki oksijeni azaltarak, kuraklık stresi oluşturur (Arslan, Aksu, \& Doğan, 2018). 
Bitkiler, kuraklık gibi olumsuz stres koşullarına maruz kaldığında bitkinin metabolizması yavaşlayarak, bozulmaya başlar. Bitkiler metabolizmalarının yavaşlamasını ve gerilemesini engellemek için prolin, glisin betain gibi bazı organik maddeler üretir. Hücre içinde zararsız ve düşük molekül ağırlıklı olan bu maddelere osmolit denir (Serraj \& Sinclair, 2002).

Stres faktörlerin olumsuz etkisini azaltmak için dışsal olarak çeşitli osmolitler uygulanmaktadır; ancak birçok bitki çeşidinde kullanılabilen prolin aminoasiti daha çok tercih edilmektedir (Hare \& Cress, 1997). Prolin, ileri yapılı bitkilerde çevresel stres faktörlerine karşı yanıt olarak oluşan, stres koşullarında miktarı artan organik bir maddedir (Rhodes \& Hanson, 1993; Ashraf \& Wu, 1994; Ali, Srivastava, \& Iqbal, 1999; Özturk \& Demir, 2002; Hsu, Hsu, \& Kao, 2003; Kishore et al., 2005; Ashraf \& Foolad, 2007; Verbruggen \& Hermans, 2008; Ali \& Ashraf, 2011). Dahası bir osmolit olan prolin stres koşullarında hücre içi osmotik basıncı düzenler, membran ve protein gibi subcelular yapıları stabilize eder, hücrenin serbest radikallerini temizleyerek hücre içi redox dengesinde rol alır (Srinivas \& Balasubramanian, 1995; Ashraf \& Foolad, 2007; Ali \& Ashraf, 2011; Moustakas, Sperdouli, Kouna, Antonopoulou, \& Therios, 2011). Dişardan prolin uygulaması yapılarak stres etkilerini azaltan çeşitli çalışmalar mevcuttur; ancak pamuk bitkisinin farklı kuraklık seviyelerinde oluşan fizyolojik ve biyokimyasal zararlanmayı dışsal osmolit uygulaması sayesinde bu zararlanmayı azaltan çalışmalar sınırlı sayıda bulunmaktadır. Bu çalışmanın amacı, farklı kuraklık seviyelerine maruz bırakılmış pamuk bitkisine dışsal prolin uygulandığı zaman hücrelerde meydana gelen fizyolojik ve biyokimyasal değişimi incelemektir. Bu çalışma ile dışsal prolin uygulamasının kuraklık zararlanmasını ne kadar değiştirdiği anlaşılacaktır. Fizyolojik ve biyokimyasal değişimlerden fotosentez ve diğer metabolik olayların temeli olan klorofil a ve $b$, karotenoid miktarı, total protein, total karbonhidrat ve bazı besin elementlerinin değişimi incelenmiştir.

\section{Materyal ve Metot}

\subsection{Denemenin Kurulması}

\subsubsection{Bitki materyali}

Kullanılan pamuk çeşidi, Güneydoğu Anadolu Bölgesi'nde yaygın olarak yetiştirilen, Bayer firması tarafından tescil edilmiş olup, kuraklığa toleranslı olarak geliştirilen Candia çeşididir.

\subsubsection{Tohum sterilizasyonu ve ekimi}

Pamuk tohumlarına bulaşmış olabilecek kontaminasyonu engellemek amaciyla \%70'lik ethanolle 30 saniye boyunca yüzey sterilizasyonu yapılmıştır. Daha sonrasında \%10 $\mathrm{NaOCl} 10$ dakika boyunca uygulanmıştır. Uygulama sonrasıda tohumlardan $\mathrm{NaOCl}$ kalıntısını yok etmek amacıyla double distile su (ddI- $\left.\mathrm{H}_{2} \mathrm{O}\right)$ ile üç kez yıkanarak tohumların sterilizasyon aşaması bitirilmiştir (Wu, Wang, \& Zhu, 2011; Can, 2013). Ekim öncesi saksılar saf su ile yıkanmış sterilize edildikten sonra içlerine süper iri perlit (0-0.5 mm) konulmuştur. Pamuk tohumları magentalar içinde çimlenme kabinlerinde filizlendirilmiştir. Filizlenen pamuk fidecikleri kabindeki steril saksılara aktarılmış, her saksıya beş adet pamuk fideciği ekilmiştir.

\section{2. İklim odasının ayarlanması}

Bitki yetiştirme ortamının sıcaklığı günlük ortalama $27 \pm$ $1^{\circ} \mathrm{C}$ olacak şekilde $\left(30^{\circ} \mathrm{C} / 26^{\circ} \mathrm{C}\right)$ ayarlanmıştır (Reddy, Kakani, Zhao, Koti, \& Gao, 2004; Salvucci \& CraftsBrandner, 2004). Bitkilerin yetiştiği ortamın ışıklandırılması 14 saat aydınlık, 10 saat karanlık olacak şekilde düzenlenmiştir. Aydınlık evre, bitkiler için geliştirilmiş floresans lambalar kullanılarak yukarıdan yapılmıştır ve 1şık yoğunluğu 350-400 $\mu \mathrm{mol} / \mathrm{m}^{2} / \mathrm{sn}$ olarak ölçülmüş̧ür. Yetiştirme ortamındaki nem oranı \%65-70 düzeyinde tutulmuştur (Rahman, Malik, \& Saleem, 2004).

Ekim sonrası bitkilere $1 / 2$ oranında seyreltilmiş hoagland besin solüsyonu verilmiştir. Otuz gün boyunca bitkiler 5-6 yapraklı evreye kadar yetiştirilmiştir. Otuz birinci günde stres uygulanmaya başlanmıştır. Kuraklık uygulaması ise besin solüsyonu içine $\% 0$ ve $\% 10$, $\% 20$ oranlarında PEG 6000 ilavesiyle gerçekleştirilmiştir. Kuraklık uygulaması iki günde bir ve ortalama 250-300 ml olacak şekilde iki kez sulanmıştır. Stres uygulaması olarak 0 (prolin verilmeyen: kontrol grup) ve $2 \mathrm{mM}$ olarak hazırlanan L-prolin çözeltisi, besin solüsyonuna eklenerek kuraklık stresiyle birlikte uygulanmıştır. Sekizinci gün başında tüm bitkiler makasla hasat edilmiştir.

\subsection{Bitki Örneklerinde Element Analizi}

Yaprakları hasat edilen pamuk bitkileri, etüvde $70^{\circ} \mathrm{C}^{\prime} \mathrm{de}$ sabit ağırlığa gelinceye kadar kurutulmuşlardır. Kuruyan pamuk bitkilerinin yaprak örnekleri eşit ağırlıklarda alınarak bitki öğütme değirmeninde öğütülmüştür (Can, 2013).

Kurutulan ve öğütülen bitki örneklerinden $0.3 \mathrm{~g}$ tartılmış, $5 \mathrm{ml} \mathrm{HNO}_{3}$ eklenmiştir Daha sonra örnekler 15 ml'lik polistren tüplere aktarılarak soğutulmuş, deiyonize su ile derecesine tamamlanmıştır. ICP-AES (Inductively Coupled Plasma Atomic Emission Spectrometer) (VarianVista, axiel) cihazı ile Elementel Analiz Laboratuarında okunarak miktarlar belirlenmiştir (Soil Survey Laboratory Methods Manual, 2004).

Çalışmamızda beş besin elementine bakılmıştır. Bunlar; Sodyum (Na), Magnezyum (Mg) , Potasyum (K), Fosfor $(\mathrm{P})$ ve Kalsiyum (Ca)'dur.

2.4. Yaprak Dokularındaki Fotosentetik Pigment Miktarının Belirlenmesi

Yaprak dokularındaki klorofil a, klorofil b ve karotenoid miktarları (Lichtenthaler, 1987)'ye göre belirlenmiştir. 0.5 $\mathrm{g}$ taze yaprak örnekleri, içinde $10 \mathrm{ml}$ soğuk aseton (\%99.9) ile havanda öğütülmüş, cam tüplere konulmuştur. Süpernatantların 663, 645 ve $470 \mathrm{~nm}$ dalga boylarındaki absorbans değerleri spektrofotometrik olarak ölçülmüştür. Değerlendirme için aşağıdaki formül kullanılarak hesaplamalar yapılmıştır.

Klorofil-a için, $\Delta \mathrm{A}_{663} \cdot 12.7-\Delta \mathrm{A}_{645} \cdot 2.69$

Klorofil-b için, $\Delta \mathrm{A}_{645} \cdot 22.9-\Delta \mathrm{A}_{663} \cdot 4.68$

Karotenoid için, $\Delta \mathrm{A}_{480}+0.114 \cdot \Delta \mathrm{A}_{663}-0.638 \cdot \Delta \mathrm{A}_{645} / 112.5$

\subsection{Total Çözünür Karbonhidrat Miktarının Belirlenmesi}

Yaprak dokularındaki toplam çözünür karbonhidrat miktarı fenol-sülfürik metoduna göre belirlenmiştir 
(Dubois, Gilles, Hamilton, Rebers, \& Smith, 1956). 0.05 gr'lık kuru örneklerin üzerine \%70'lik etil alkol eklenerek 60 dakika boyunca $80^{\circ} \mathrm{C}^{\prime}$ ye ayarlanmış sıcak su banyosunda tutulmuştur. Bu sürenin sonunda tüpler 3500 rpm'de 20 dakika santrifüj edilmiştir. Çalışmada deney tüplerine $1000 \mu \mathrm{l}$ süpernatant, $300 \mu \mathrm{l} \% 5^{\prime}$ lik fenol ve 2000 $\mu \mathrm{l}$ derişik sülfürik asit $\left(\mathrm{H}_{2} \mathrm{SO}_{4}\right)$ eklenerek vortekslenmiştir. Daha sonra karışımların absorbans değerleri, $490 \mathrm{~nm}$ dalga boyunda spektrofotometrik okunarak belirlenmiştir. Standart olarak glukoz kullanılmış, grafik eğrisi oluşturularak toplam miktar hesaplanmıştır.

\subsection{Total Protein Miktarının Belirlenmesi}

Total protein miktarı analizleri (Bradford, 1976) göre BSA (Bovine Serum Albumine) standartları kullanılarak yapılmıştır. Standartlar hazırlandıktan sonra her bir gruptan 3 tekrarlı olmak üzere 50'şer $\mu$ l örnek alınıp eppendorfa konmuştur. Bunun üzerine Coomasie Brillant Blue (CBB) isimli protein boyasından $950 \mu$ l konulmuştur. Örnekler köre karşı Shimadzu UV spektrofotometre cihazı ile 595 nm'de okunmuştur. Hazırlanan standart yardımıyla grafikler hesaplanmıştır. Çözünebilen total protein miktarı $\mathrm{mg} \mathrm{ml}^{-1}$ yaş ağırlık olarak belirlenmiştir.

\section{7. İstatistik Analizi}

Deneme deseni iki kez kurulmuştur, analizlerde bu deneme serilerinin yaprak materyalleri kullanılmıştır. Büyüme parametreleri iki kez tekrar edilirken $(n=10)$ diğer analizler üç tekerrürlü olup üç kez tekrar edilmiştir. Üçüncü analizlerin tekrarı, birinci ve ikinci deneme serilerinin yapraklarının birleştirilmesiyle yapılmıştır. Her bir analiz, IBM SPPS Statistic 26.0 programinda ANOVA kullanılarak yapılmıştır.

\section{Bulgular}

\subsection{Klorofil a ve b İçeriği}

Klorofil a içeriğinin, dışsal prolin uygulaması yapılmadan sadece kuraklık uygulamasının yapıldığı gruplarda (\%0, $\% 10, \% 20)$, kuraklık şiddeti arttıkça kontrol grubuna kıyasla azaldığı görülmüştür. Sadece kuraklık uygulanan bitkilere kıyasla eş zamanlı prolin ve kuraklık uygulamasının yapıldığı gruplarda klorofil miktarında artış görülmüştür. Sadece kuraklık uygulaması yapılan gruplarda en yüksek klorofil a içeriği, kontrol grubunda $7.58 \mu \mathrm{g} \mathrm{g} \mathrm{g}^{-1}$ bulunmuştur. Bu kuraklık gruplarına dişsal prolin uygulaması yapıldığında en yüksek klorofil içeriği $7.12 \mu \mathrm{g} \quad \mathrm{g}^{-1}$ olarak yine kontrol grubunda bulunmuştur. $(\mathrm{p}<0.05)$. Şekil 1, farklı kuraklık seviyelerinde yetişen pamuk bitkisine dişsal prolin uygulamasının klorofil a üzerinde etkisini gösterirken, Şekil 2'de farklı kuraklık seviyelerinde yetişen pamuk bitkisine dışsal prolin uygulamasının klorofil b üzerinde etkisini göstermektedir.

Klorofil b içeriğinin, dışsal prolin uygulaması yapılmaksızın sadece kuraklık uygulamasının yapıldığı gruplarda, kuraklık şiddeti arttıkça kontrol grubuna kıyasla azaldığı görülmüştür. Dışsal prolin uygulaması ve kuraklık uygulamasının birlikte yapıldığı gruplarda sadece kuraklık uygulama grubuna $(0 \mathrm{mM})$ göre klorofil b miktarında artış görülmüştür. Sadece kuraklık uygulaması yapılan gruplarda en yüksek toplam klorofil içeriği kontrol grubunda $8.05 \mu \mathrm{g} \mathrm{g}^{-1}$ olarak belirlenirken bu kuraklık gruplarına dışsal prolin uygulaması yapıldığında klorofil içeriği $7.99 \mu \mathrm{g} \mathrm{g}^{-1}$ olarak yine kontrol grubunda bulunmuştur $(\mathrm{p}<0.05)$.

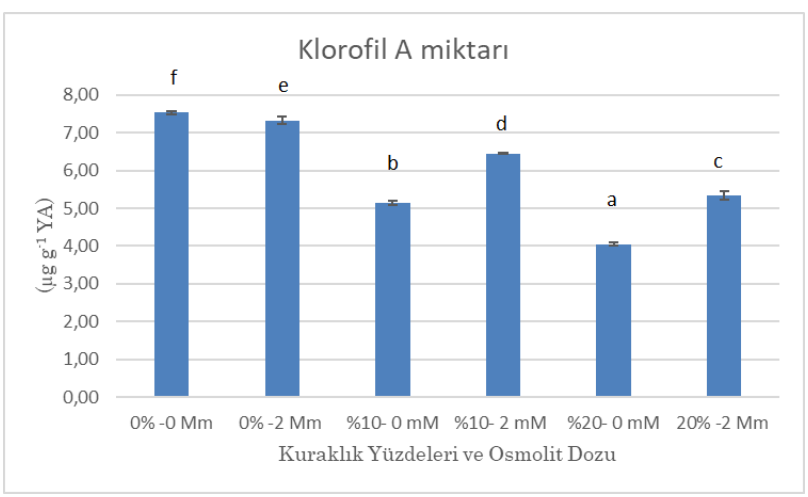

Şekil 1. Farklı kuraklık seviyelerinde yetişen pamuk bitkisine dışsal prolin uygulamasının $(2 \mathrm{mM})$ klorofil a üzerinde etkisi (hata çubukları standard sapmayı göstermektedir) $(\mathrm{N}=9)$

Figure 1. Effect of exogenous proline application $(2 \mathrm{mM})$ on chlorophyll a grown in different drought levels on cotton plants (error bars show standard deviation) $(\mathrm{N}=9)$

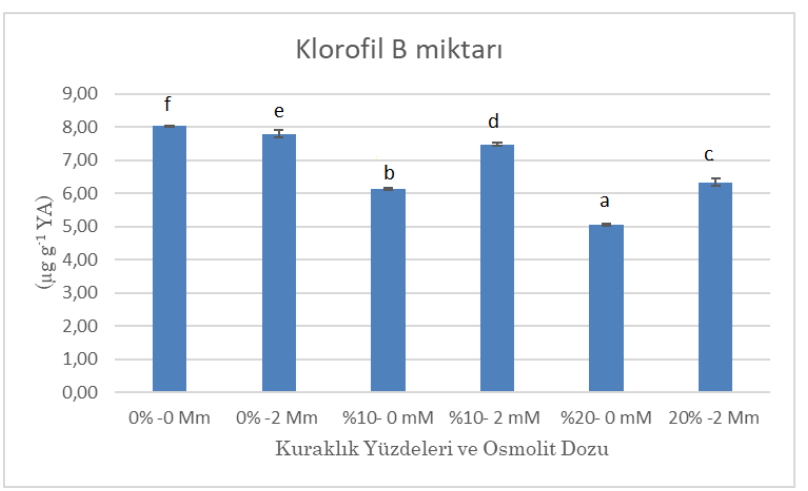

Şekil 2. Farklı kuraklık seviyelerinde yetişen pamuk bitkisine dışsal prolin uygulamasının $(2 \mathrm{~mm})$ klorofil b üzerinde etkisi (hata çubukları standard sapmayı göstermektedir) $(\mathrm{N}=9)$

Figure 2. Effect of exogenous proline application $(2 \mathrm{mM})$ on chlorophyll $\mathrm{b}$ grown in different drought levels on cotton plants (error bars show standard deviation) $(\mathrm{N}=9)$

Toplam karotenoid içeriğinin, sadece kuraklık uygulamasının yapıldığı gruplarda, kuraklık şiddeti arttıkça kontrol grubuna kıyasla arttığı görülmüştür. Dışsal prolin uygulaması ve kuraklık uygulamasının birlikte yapıldığı bitkilerde sadece kuraklık uygulama grubuna $(0 \mathrm{mM})$ göre karotenoid miktarında artış görülmüştür. Sadece kuraklık uygulaması yapılan gruplarda en yüksek toplam karotenoid içeriği, kontrol grubunda, $1.52 \mu \mathrm{g} \mathrm{g-1}$ olarak bulunurken bu kuraklık gruplarına dışsal prolin uygulaması yapıldığında karotenoid içeriği $1.62 \mu \mathrm{g} \mathrm{g}^{-1}$ olarak bulunmuştur $(\mathrm{p}<0.05)$ (Şekil 3).

\subsection{Toplam Çözünmüş Karbonhidrat İçeriği}

Sadece kuraklık uygulamasının yapıldığı gruplarda, kuraklık şiddeti arttıkça toplam çözünmüş karbonhidrat içeriğinin kontrole kıyasla stres gruplarında arttığ1 görülmüştür. Dışsal prolin uygulaması ve kuraklık uygulamasının birlikte yapıldığı gruplarda sadece kuraklık uygulama grubuna $(0 \mathrm{mM})$ göre çözünmüş karbonhidrat miktarında azalma görülmüştür. Sadece kuraklık uygulaması yapılan gruplarda en yüksek toplam çözünmüş karbonhidrat içeriği \%20'lik grupta, 19. $26 \mathrm{mg}$ $\mathrm{ml}^{-1}$ olarak bulunurken bu kuraklık gruplarına dişsal 
prolin uygulaması yapıldığında çözünmüş karbonhidrat içeriği \%20'lik grupta $17.6 \mathrm{mg} \mathrm{ml}^{-1}$ olarak bulunmuştur $(\mathrm{p}<0.05)$ (Şekil 4).

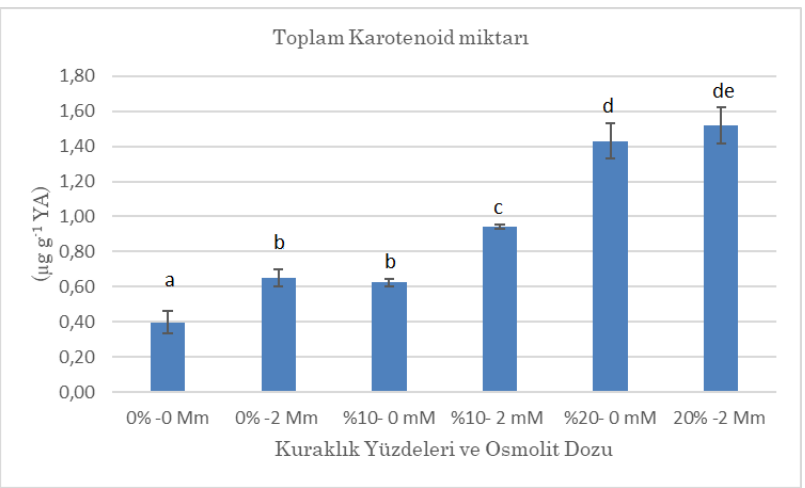

Şekil 3. Farklı kuraklık seviyelerinde yetişen pamuk bitkisine dışsal prolin uygulamasının $(2 \mathrm{~mm})$ karotenoid üzerinde etkisi (hata çubukları standard sapmayı göstermektedir) (N=9)

Figure 3. Effect of exogenous proline application $(2 \mathrm{mM})$ on content of total carotenoid grown in different drought levels on cotton plants (error bars show standard deviation) $(\mathrm{N}=9)$

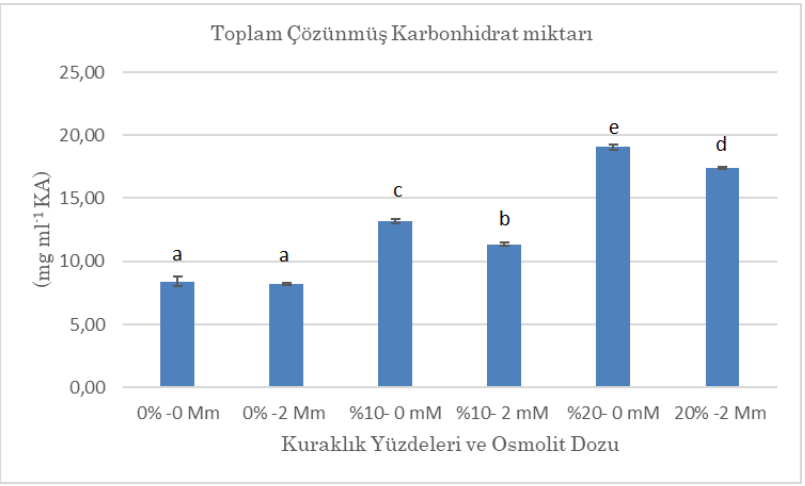

Şekil 4. Farklı kuraklık seviyelerinde yetişen pamuk bitkisine dışsal prolin uygulamasının (2 $\mathrm{mm})$ toplam çözünmüş karbonhidrat üzerinde etkisi (hata çubukları standard sapmayı göstermektedir) $(\mathrm{N}=9)$

Figure 4. Effect of exogenous proline application $(2 \mathrm{mM})$ on content of total soluble carbohydrate grown in different drought levels on cotton plants (error bars show standard deviation) $(\mathrm{N}=9)$

\subsection{Toplam Çözünmüş Protein İçeriği}

Sadece kuraklık uygulamasının yapıldığı gruplarda kuraklık şiddeti arttıkça kontrol grubuna kıyasla toplam çözünmüş protein içeriğinin arttığ görülmüştür. Dişsal prolin uygulaması ve kuraklık uygulamasının birlikte yapıldığ 1 bitkilerde sadece kuraklık uygulama grubuna $(0$ $\mathrm{mM})$ göre çözünmüş protein miktarında artış görülmüştür. Sadece kuraklık uygulaması yapılan gruplarda en yüksek toplam çözünmüş protein içeriği 4.37 mg ml-1 olarak \%20'lik grupta bulunurken bu kuraklık gruplarına dışsal prolin uygulaması yapıldı̆̆ında çözünmüş protein içeriği $3.12 \mathrm{mg} \mathrm{ml}^{-1}$ olarak \%20'lik grupta olarak bulunmuştur $(\mathrm{p}<0.05)$ (Şekil 5). Prolin bir aminoasittir ve dişsal prolin uygulamasının mevcut protein seviyesinde artışa neden olduğu düşünülmektedir.

\subsection{Bazı Besin Element İçeriği}

Sadece kuraklık uygulamasının yapıldı̆̆ı gruplarda kuraklık şiddeti arttıkça kontrol grubuna kıyasla Ca element miktarının azaldığı görülmüştür. Dışsal prolin uygulaması ve kuraklık uygulamasının birlikte yapıldığ gruplarda sadece kuraklık uygulama grubuna $(0 \mathrm{mM})$ göre Ca elementi miktarında artış görülmüştür. Sadece kuraklık uygulaması yapılan gruplarda en yüksek Ca içeriği $427.53 \mathrm{mg} \mathrm{L}^{-1}$ olarak \%0'lik grupta bulunurken, bu kuraklık gruplarına dışsal prolin uygulaması yapıldı ğında en yüksek Ca elementi içeriği $425.53 \mathrm{mg} \mathrm{L}^{-1}$ olarak yine $\% 0^{\prime}$ lık grupta bulunmuştur $(\mathrm{p}<0.05)$. (Şekil 6 'da farklı kuraklık seviyelerinde yetişen pamuk bitkisine dişsal prolin uygulamasının toplam Ca element miktarı üzerinde etkisini göstermektedir).

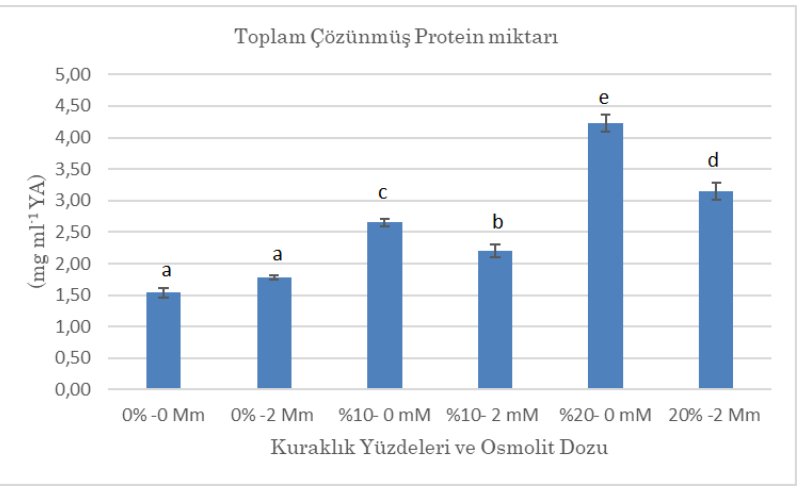

Şekil 5. Farklı kuraklık seviyelerinde yetişen pamuk bitkisine dişsal prolin uygulamasının $(2 \mathrm{~mm})$ toplam çözünmüş protein üzerinde etkisi (hata çubukları standard sapmayı göstermektedir) $(\mathrm{N}=9)$.

Figure 5. Effect of exogenous proline application $(2 \mathrm{mM})$ on content of total soluble protein grown in different drought levels on cotton plants (error bars show standard deviation) $(\mathrm{N}=9)$

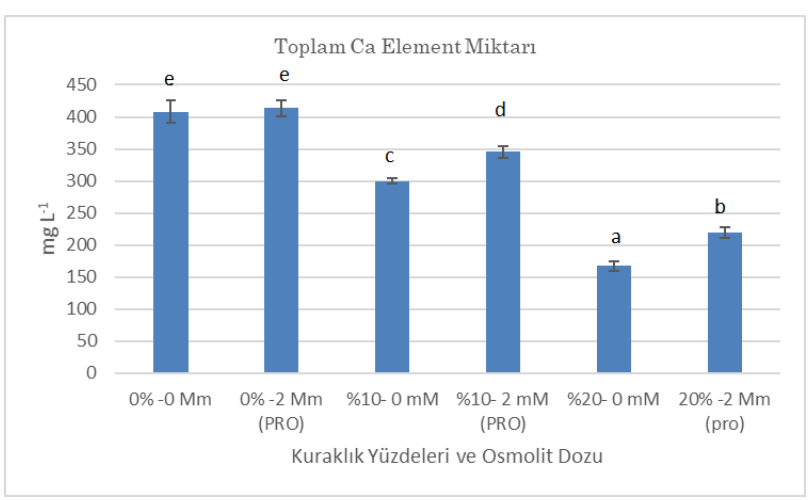

Şekil 6. Farklı kuraklık seviyelerinde yetişen pamuk bitkisine dışsal prolin uygulamasının $(2 \mathrm{~mm})$ toplam Ca element miktarı üzerinde etkisi (hata çubukları standard sapmayı göstermektedir) $(\mathrm{N}=9)$

Figure 6. Effect of exogenous proline application $(2 \mathrm{mM})$ on content of total Ca element grown in different drought levels on cotton plants (error bars show standard deviation) $(\mathrm{N}=9)$

Sadece kuraklık uygulamasının yapıldığ kuraklık şiddeti arttıkça kontrol grubuna kıyasla K element miktarının arttığı görülmüştür. Dişsal prolin uygulaması ve kuraklık uygulamasının birlikte yapıldığı gruplarda sadece kuraklık uygulama grubuna göre $\mathrm{K}$ elementi miktarında azalma görülmüştür. Sadece kuraklık uygulaması yapılan gruplarda en yüksek toplam çözünmüş K elementi içeriği $633.45 \mathrm{mg} \mathrm{L} \mathrm{L}^{-1}$ olarak \%20'lik grupta bulunurken bu kuraklık gruplarına dışsal prolin uygulaması yapıldığında çözünmüş $K$ elementi içeriği $630.13 \mathrm{mg} \mathrm{L}^{-1}$ olarak yine \%20'lik grupta bulunmuştur $(\mathrm{p}<0.05)$ (Şekil 7). Sadece kuraklık uygulamasının yapıldığ gruplarda (\%0, \%10, \%20) Mg element miktarı, 
kuraklık şiddeti arttıkça kontrol grubuna kıyasla azaldığı görülmüştür. Dışsal prolin uygulaması $(2 \mathrm{mM})$ ve kuraklık uygulamasının birlikte yapıldı $\breve{1} 1(\% 0, \% 10, \% 20)$ gruplarda sadece kuraklık uygulama grubuna $(0 \mathrm{mM})$ göre $\mathrm{Mg}$ elementi miktarında artış görülmüştür. Sadece kuraklık uygulaması yapılan gruplarda en yüksek $\mathrm{Mg}$ elementi içeriği $185.5 \mathrm{mg} \mathrm{L}^{-1}$ olarak \%0'lık grupta bulunurken bu kuraklık gruplarına dışsal prolin uygulaması yapıldı ğında en yüksek Mg elementi içeriği 205.45 mg L-1 olarak \%0'lik grupta bulunmuştur $(\mathrm{p}<0.05)$ (Şekil 8). Sadece kuraklık uygulamasının yapıldığı gruplarda, kuraklık şiddeti arttıkça kontrol grubuna kıyasla Na element miktarının azaldığ1 görülmüştür. Dişsal prolin uygulaması ve kuraklık uygulamasının birlikte yapıldığı zaman sadece kuraklık uygulama grubuna $(0 \mathrm{mM})$ göre $\mathrm{Na}$ elementi miktarında artış görülmüştür. Sadece kuraklık uygulaması yapılan gruplarda en yüksek toplam çözünmüş Na elementi içeriği $149.8 \mathrm{mg} \mathrm{L}^{-1}$ olarak \%0'lik grupta bulunurken bu kuraklık gruplarına dişsal prolin uygulaması yapıldığında çözünmüş $\mathrm{Na}$ elementi içeriği $185.5 \mathrm{mg} \mathrm{L}^{-1}$ olarak \% 0'llk grupta bulunmuştur $(\mathrm{p}<0.05)$ (Şekil 9). Sadece kuraklık uygulamasının yapıldığı gruplarda, kuraklık şiddeti arttıkça kontrol grubuna kıyasla P element miktarının azaldığı görülmüştür. Dışsal prolin uygulaması ve kuraklık uygulamasının birlikte yapıldığı bitkilerde sadece kuraklık uygulama grubuna (0 $\mathrm{mM}$ ) göre P elementi miktarında artış görülmüştür. Sadece kuraklık uygulaması yapılan gruplarda en yüksek P elementi içeriği $238.4 \mathrm{mg} \mathrm{L-1}$ olarak \%0'lik grupta bulunurken bu kuraklık gruplarına dişsal prolin uygulaması yapıldığında en yüksek $\mathrm{P}$ elementi içeriği $272.12 \mathrm{mg} \mathrm{L}^{-1}$ olarak \% $0^{\prime}$ lik grupta bulunmuştur $(\mathrm{p}<0.05)$ (Şekil 10).

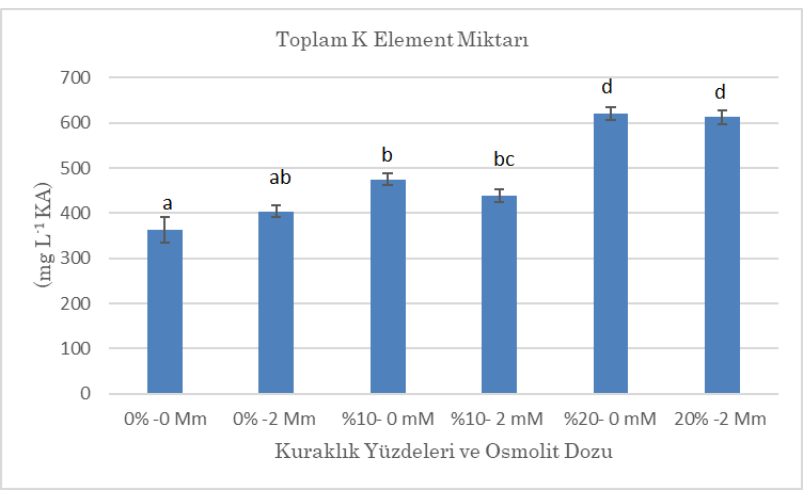

Şekil 7. Farklı kuraklık seviyelerinde yetişen pamuk bitkisine dışsal prolin uygulamasının $(2 \mathrm{~mm})$ toplam $\mathrm{K}$ element miktarı üzerinde etkisi (hata çubukları standard sapmayı göstermektedir) $(\mathrm{N}=9)$

Figure 7. Effect of exogenous proline application $(2 \mathrm{mM})$ on content of total $\mathrm{K}$ element grown in different drought levels on cotton plants (error bars show standard deviation) $(\mathrm{N}=9)$

\section{Tartışma}

Pamuk, kurak ve yarı kurak koşullarda yetişebilen önemli lif bitkilerinden biridir. Pamuk bitkisi üretiminde Güneydoğu Anadolu Bölgesi lider konumundadır.

Pamuk üretiminde Şanlıurfa ili ilk sırada yer almaktadır. Şanlıurfa ili çoğunlukla sıcak ve kurak geçmektedir. Kuraklığın pamuk bitki metabolizmasına ne derece etkilediğini bilmek, kuraklığın oluşturduğu zararları azaltmak, pamuk üretimi için önem arz etmektedir.

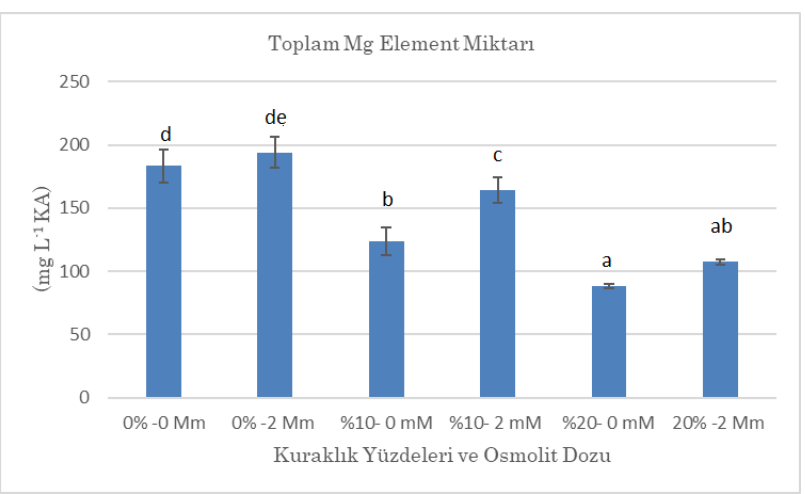

Şekil 8. Farklı kuraklık seviyelerinde yetişen pamuk bitkisine dısssal prolin uygulamasının ( $2 \mathrm{mM}$ ) toplam Mg element miktarı üzerinde etkisi (hata çubukları standard sapmayı göstermektedir)( $\mathrm{N}=9$ )

Figure 8 . Effect of exogenous proline application $(2 \mathrm{mM})$ on content of total $\mathrm{Mg}$ element grown in different drought levels on cotton plants (error bars show standard deviation) $(\mathrm{N}=9)$

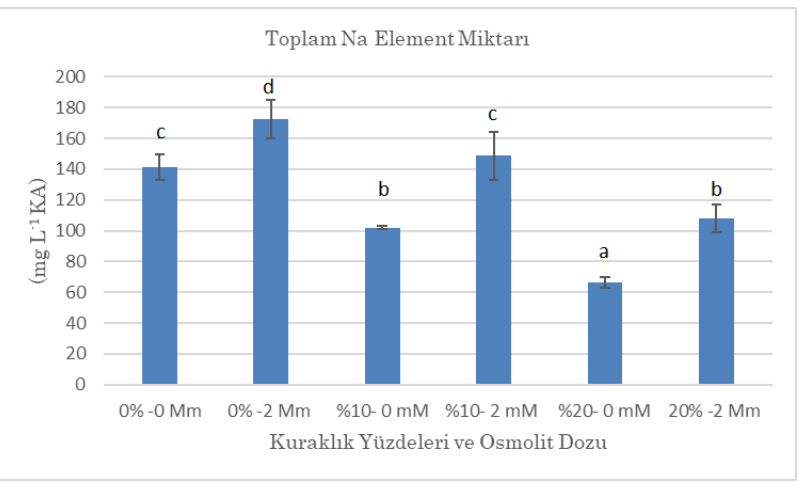

Şekil 9. Farklı kuraklık seviyelerinde yetişen pamuk bitkisine dışsal prolin uygulamasının $(2 \mathrm{mM})$ toplam Na element miktaı üzerinde etkisi (hata çubukları standard sapmayı göstermektedir) $(\mathrm{N}=9)$

Figure 9. Effect of exogenous proline application $(2 \mathrm{mM})$ on content of total $\mathrm{Na}$ element grown in different drought levels on cotton plants (error bars show standard deviation) $(\mathrm{N}=9)$

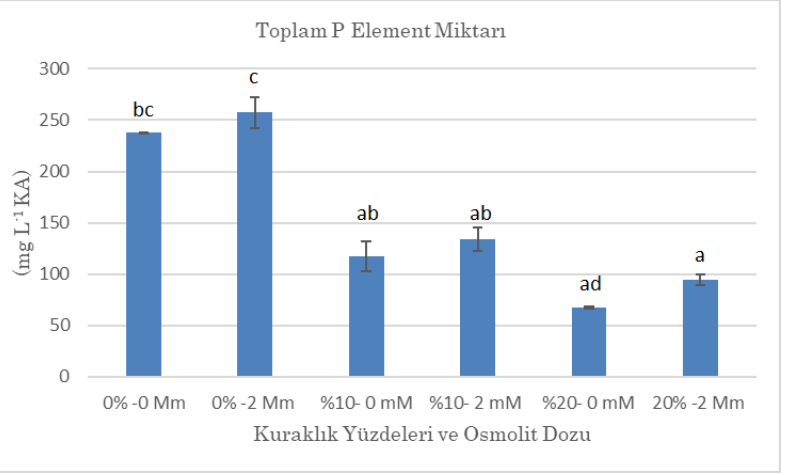

Şekil 10. Farklı kuraklık seviyelerinde yetişen pamuk bitkisine dışsal prolin uygulamasının $(2 \mathrm{mM})$ toplam P element miktarı üzerinde etkisi (hata çubukları standard sapmayı göstermektedir) $(\mathrm{N}=9)$

Figure 10. Effect of exogenous proline application $(2 \mathrm{mM})$ on content of total $\mathrm{P}$ element grown in different drought levels on cotton plants (error bars show standard deviation) $(\mathrm{N}=9)$

Pamuk bitkisi, her ne kadar kurak ortamlarda yetişse de kuraklık stresi pamuk bitkisinin büyüme ve gelişmesini kisıtlamakta ve verimi azaltmaktadır (Ullah, 2008; Can, 2013). Kuraklık stresine maruz kalan bitkilerin 
metabolizmalarında fizyolojik ve biyokimyasal değişiklikler olur. Bu değişikliğin temelinde (ROS) reaktif oksijen türlerinin üretimi yatmaktadır. Mitokondri ve kloroplast organelleri, reaktif oksijen türlerinin üretildiği önemli bölgelerdir. Reaktif oksijen türleri lipid, protein ve nükleik asitleri okside ederek bitki metabolizmasına oldukça zarar vermektedirler (Clemens, 2001; Shafaqat, Shengguan, Fanrong, Boyin, \& Guoping, 2012). Kuraklığın etkisiyle yapraklarda toplam çözünür şeker, toplam amino azot ve polifenol gibi antioksidan miktarlarında değişimler olur (Başal \& Aydın, 2006). Fizyolojisi ve biyolojisi gerileyen pamuk bitkisinde verim düşer, hayati fonksiyonlar yavaşlar. Stres faktörlerinin oluşturduğu zararın etkisini azaltmak amacıyla çeşitli osmolitlerin etkisi araştırılmıştır (Rhodes \& Hanson, 1993; Ashraf \& Wu, 1994; Ali et al., 1999; Özturk \& Demir, 2002; Hsu et al., 2003; Kishore et al., 2005; Ashraf \& Foolad, 2007; Verbruggen \& Hermans, 2008; Ali \& Ashraf, 2011). Bu çalışmada farklı kuraklık seviyelerinde yetiştirilen pamuk bitkisine kuraklık stresiyle beraber disssal prolin uygulamasının yapıldığında kuraklık stresinin olumsuz etkilerinin ne derece iyileştiği araştırılmıştır.

Pamuk bitkisinin birçok çeşidi kuraklık stresinden olumsuz etkilenmektedir. Kurak stresi oluştuğunda fotosentez oranında azalmalar, total klorofil değişimleri, fotosentetik verim, klorofil a ve b'nin miktarı ve oranlarında çoğunlukla azalmalar görülmüştür (Faver, Gerik, Thaxton, \& El-Zik, 1996; Pettigrew, Molin, \& Stetina, 2005; Can, 2013). Kuraklık stresinin şiddeti arttıkça klorofil a ve $\mathrm{b}$ içeriklerinin azalması bizim bulgularımızla benzerlik göstermektedir. Bu araştırmada dışsal prolin uygulamasıyla kontrol grubuna göre azalan klorofil a ve b içeriklerinde iyileşme görülerek klorofil miktarında artış olmuştur. Bu araştırmada elde edilen bulgular, kuraklık stresinin etkisiyle azalan su miktarına bağlı olarak stomaların kapatıldığını, $\mathrm{CO}_{2}$ derişiminin azaldığını, bu durumun fotoinhibisyon ve foto oksidasyona neden olduğunu bildiren Flexas ve Medrano (2002)'nin bulguları ile örtüşmektedir. Bu dolaylı tepkime sonucu klorofilin molekül yapısında bozukluklar olabileceği yönündeki bulgular ile literatürde fotosentetik pigment miktarının azaldığını bildiren bazı araştırma bulguları ile benzerlik göstermektedir (Thimmanaik, Kumar, Kumari, Suryanarayana, \& Sudhakar, 2002; Parida, Dagaonkar, Phalak, Umalkar, \& Aurangabadkar, 2007; Guerfel, Baccouri, Boujnah, Chaibi, \& Zarrouk, 2009; Nikolaeva, Maevskaya, Shugaev, \& Bukhov, 2010). Çınar (2003); Kalefetoğlu ve Ekmekçi (2005)'nin karotenoidlerin, hücre içinde iken proteinlere zayıf bağlarla tutunan, pigmenti izomerasyondan, oksidasyondan ve bozulmaktan koruyan bir antioksidandır şeklindeki bulguları, araştırma bulguları ile benzerlik göstermiştir. Kuraklık stresi koşullarında karotenoid içeriğinin artması, bitkinin antioksidan mekanizmasının aktifleştirdiğini ve kuraklık stresinin olumsuz etkilerini azaltmaya çalıştığını söyleyebiliriz. Kuraklık stresiyle beraber dişsal prolin uygulanması, kontrol grubuna göre karotenoid miktarını azaltmıştır.

Pamuk bitkisinde kuraklık stresinin etkisiyle fotosentez mekanizmasında yavaşlamalar olur. Fotosentez mekanizması yavaşlamasıyla karbonhidrat mekanizmasında bozulmalar gerçekleşir; çözünmüş karbonhidrat miktarlarında çoğunlukla artış meydana gelir (Pelleschi et al., 1997; Kerepesi \& Galiba, 2000; Kim,
Mahe, Brangeon, \& Prioul, 2000; Sánchez, De Andrés, Tenorio, \& Ayerbe, 2004; Can, 2013). Bu araştırmada kuraklık şiddetinin artışına paralel olarak total çözünmüş karbonhidrat miktarının artması yukarıda bahsedilen literatür bulgularıyla benzerlik göstermektedir. Total çözünmüş karbonhidrat miktarında kuraklık stresiyle beraber dişsal prolin uygulanan bitkilerde kontrol grubuna kıyasla azalma görülmüştür. Bu sonuç bize prolinin fotosentez mekanizmasında iyileşmeler meydana getirdiğini düşündürmektedir. Düzelmeye başlayan fotosentez ile karbonhidrat üretiminde iyileşmeler olmuş olabilir.

Kuraklık stresinin olumsuz etkileri, fotosentez mekanizmasından nükleik asit sentezi ve protein mekanizmasına kadar birçok metabolik olayı etkilemektedir. Nükleik asit metabolizmasında meydana gelen gerilemenin, protein metabolizmasinı da yavaşlattığı bildirilmiştir (Çırak \& Esendal, 2006). Kurak koşullarda protein sentez hızı azalırken protein yapılarında parçalanmalar gerçekleşir (Chartzoulaki, Patakas, Kodifis, Bosabalidis, \& Nostou, 2002; Parida et al., 2007). Bu parçalanmalardan dolayı çözünmüş protein miktarında artış olmuş olabilir. Kuraklık stresi arttıkça, çözünmüş protein miktarının artması yukarıda bahsedilen bulgularla benzerlik göstermektedir. Kuraklık stresiyle beraber dışsal prolin uygulanması, stres gruplarında toplam çözünmüş protein miktarını kontrol gruplarına göre azaltmıştır. Dışsal prolin uygulaması ile protein mekanizmasında parçalanmaların azaldığı, bozulan protein mekanizmasında iyileşme olduğunu söyleyebiliriz.

Kuraklık stresi; bitkilerin mineral madde taşınımını, köklerin gelişimini, topraktaki besin transportunu önemli derecede etkilemektedir (Fageria, Baligar, \& Clark, 2002; Samarah, Mullen, \& Cianzio, 2004). Bitkiler kuraklık stresi altındayken Ca elementinin alımının azaldığı, bununla birlikte kalsiyum elementinin osmatik basincin düzenlenmesinde rol oynadığı bildirilmiştir. Bu element kuraklık ve tuzluluk stres mekanizmasinin olumsuz etkilerini tolere edip, sinyal iletim mekanizmasında önemli rol oynadığı bilinmektedir (Bartels \& Sunkar, 2005).

Potasyum elementi, bitkilerin kuraklık stresinin olumsuz etkilerine karşı dayanıklılık sağlanmasında önemli rol oynar. Potasyum elementinin derişiminin artmasıyla turgor basıncının dengelendiği Mengel ve Arneke (1982), terlemenin azaldığ 1 Andersen, Jensen, ve Lösch (1992), stomaların açlıp, kapanma mekanizması değişerek hücrenin osmoregülasyonunu, enerji mekanizmasını, protein sentezini ve içsel dengeyi (homeostasis) etkiler (Beringer \& Trolldenier,1978; Marschner, 1995). Bu bulgular ile bizim araştırmanın bulguları benzerlik göstermiştir.

Araştırma bulgularında kuraklık şiddeti arttıkça K elementi artmış, Ca elementi azalmıştır. Eş zamanlı prolin ve kuraklık stresi uygulanan bitkilerde kontrol gruplarını kıyasladığımızda Ca elementinin alımı artmış, K elementinin alımı azalmıştır. Prolin osmolitinin uygulanması daha fazla K elementinin kaybını önlemiş, gerekli olan Ca elementinin almasına yardımcı olmuş olabilir.

Kuraklık stresinin etkisiyle Mg element miktarının 
azalması, fotosentez mekanizmasinda bozulmalar olduğunu, $\mathrm{P}$ ve $\mathrm{Na}$ element değerinin azalması bitki gelişiminde yavaşlama olduğunu, yeni sürgünleri meydana getiremediğini düşündürmektedir. Havlin, Beaton, Tisdale, ve Nelson (2004)' in, kuraklık stresi altında yetişen bitkilerde $\mathrm{Mg}$, $\mathrm{Fe}$ ve $\mathrm{P}$ iyonlarının alım mekanizmalarının bitkiden bitkiye değiştiğini hatta bu elementlerin noksanlığında bitkide toksik etkilerin görüldüğünü bildiren çalışma bulgularıyla benzerdir. Dışsal prolin uygulaması sonucu $\mathrm{Na}, \mathrm{Mg}$ ve P elementleri kontrole göre artmıştır, azalan bu element miktarının kontrole göre artması kuraklık stresinin olumsuz etkisini azaltmasından kaynaklanıyor olabilir.

Çalışma sonucunda farklı kuraklık stresinin etkisiyle klorofil a ve b içeriklerinde bozulmaya bağlı azalmalar görülürken toplam karotenoid miktarında, toplam çözünmüş protein ve karbonhidrat miktarlarında artış görülmüştür. K elementi kuraklık şiddetinin artmasına bağlı olarak artış gösterirken $\mathrm{Ca}, \mathrm{Mg}, \mathrm{P}$ ve $\mathrm{Na}$ elementlerinde azalmalar görülmüştür. $\mathrm{Bu}$ kuraklık uygulama gruplarına dişardan prolin uygulanmasıyla incelenen parametre değerlerinde iyileşme olduğu görülmüştür. Prolin gibi çeşitli osmotik koruyucuların uygulanması ile bitkilerde kuraklık stresinin oluşturduğu zararın etkisi azaltılabilir. Böylelikle çiftçilerin ürün kaybı yaşamasının önüne geçilebileceği ön görülmektedir.

Bu çalışmaya paralel olarak daha detaylı bilgi elde etmek için farklı parametreler incelenebilir. Örneğin kuraklık stresi altında osmotik uygulamanın hangi tip karbonhidratların oluştuğunu ve bu karbonhidratların derişimini, ekstra hangi bileşiklerin oluştuğu araştırılabilir. Fotosentez ve pigment metabolizmasında oluşan değişimlerin protein profilleri, sodyum dodesil sülfat poliakrialamid jel elektroforezi (SDS-PAGE) tekniği kullanılarak araştırılabilir. Antioksidant sistemin enzimatik bileşenlerinin aktivite miktarı ve izo enzimlerin belirlenmesi, osmotik koruyucuların kuraklık tolerans mekanizmasının aydınlatılmasında etkili olacağını düşünmekteyiz.

Teşekkür: $\mathrm{Bu}$ makalede elde edilen sonuçlar Nimet Kılınçoğlu' nun 18162 nolu doktora tez proje çalışmasından elde edilmiștir. Tezin finansal desteklemesi Harran Üniversitesi Bilimsel Araştırma Projeleri Koordinatörlüguünce yapılmıştır.

\section{Kaynaklar}

Ali, G., Srivastava, P.S., \& Iqbal, M. (1999). Proline accumulation, protein pattern and photosynthesis in regenerants grown under $\mathrm{NaCl}$ stress. Biologia Plantarum, 42, 89-95. https://doi.org/10.1023/ A:1002127711432

Ali, Q., \& Ashraf, M. (2011). Exogenously applied glycinebetaine enhances seed and seed oil quality of maize (Zea mays L.) under water deficit conditions. Environmental and Experimental Botany, 71(2), 249-259. https://doi.org/10.1016/j.envexpbot.2010.12.009

Andersen, N., Jensen, R. \& Lösch, R. (1992). The interaction effects of potassium and drought in field-grown barley. 1. Yield, water-use efficiency and growth. Journal Acta Agriculturae Scandinavica, Section B Soil $\mathcal{E}$ Plant Science, 42, 34-44. https://doi.org/10.1080/ 09064719209410197

Arslan, M., Aksu, E., \& Doğan E. (2018). Kuraklık stresine tolerans bakımından iki mürdümük genotipinin değerlendirilmesi. Türk Tarım ve Doğa Bilimleri Dergisi, 5(3), 261-267. https://doi.org/10.30910/ $\underline{\text { turkjans.448349 }}$

Ashraf, M., \& Foolad, M.R. (2007). Roles of glycine betaine and proline in improving plant abiotic stres resistance. Environmental and Experimental Botany, 60(3), 206-216. https://doi.org/10.1016/ j.envexpbot.2005.12.006
Ashraf, M., \& Wu, L. (1994). Breeding for salinity tolerance in plants. Critical Reviews in Plant Sciences, 13(1), 17-42. https://doi.org/10.1080/ 07352689409701906

Atasoy, G. (2013). Pamukta (Gossypium Spp.) kuraklık ve sicaklık stresinin bazı agronomik, fizyolojik ve biyokimyasal özelliklere etkisinin incelenmesi (Yüksek Lisans Tezi). Ege Universitesi, İzmir, Türkiye.

Bartels, D., \& Sunkar, R. (2005). Drought and salt tolerance in plants. Critical Reviews in Plant Sciences, 24(1), 23-58. https://doi.org/10.1080/ 07352680590910410

Başal, H., \& Aydın, Ü. (2006). Water stress in cotton (Gossypium hirsutum L.). Journal of Agriculture Faculty of Ege University, 43(3), 101-111.

Beringer, H., \& Trolldenier, G. (1978). Influence of K nutrition on response to environmental stres. Potassium research - review and trends. Proceedings of the 11th Congress the International Potash Institute, 1978 1979., Hannover-Kirchrode, Germany, Ipi Press, $p p$. (189-222)

Bradford, M. (1976). A rapid and sensitive method for the quantitation of microgram quantities of protein utilizing the principle of protein-dye binding. Analytical Biochemistry, 72(1-2), 248-254. https://doi.org/ 10.1016/0003-2697(76)90527-3

Can, N. (2013). Pamuk Çeşitlerinde (Gossypium hirsutum L. ) Kuraklik Stresi Etkilerinin Fizyolojik Olarak Incelenmesi (Yüksek Lisans Tezi). Harran Universitesi, Şanlıurfa, Türkiye.

Chartzoulaki, K., Patakas, A., Kodifis, G., Bosabalidis, A., \& Nostou, A. (2002). Water stress affects leaf anatomy, gas exchange, water relations and growth of two avocado cultivars. Scientia Horticulturae, 95(1-2), 39 50. https://doi.org/10.1016/S0304-4238(02)00016-X

Çınar, I. (2003). Carotenoid Pigment Loss of Freeze-dried Plant Samples under Different Storage Conditions, Food Science and Technology/LWT, 37(3), 363-367. https://doi.org/10.1016/j.lwt.2003.10.006

Çırak, C., \& Esendal, E. (2006). Soyada Kuraklık Stresi. OMÜ Ziraat Fakultesi Dergisi, 21(2), 231-237.

Clemens, S. (2001). Molecular mechanisms of plant metal tolerance and homeostasis. Planta, 212, 475-786. https://doi.org/10.1007/ $\underline{\mathrm{s} 004250000458}$

Dubois, M., Gilles, A., Hamilton, K., Rebers, A., \& Smith, F. (1956). Colorimetric method for determination of sugars and related substances. Analytical Chemistry, 28(3), 350-356. https://doi.org/ 10.1021/ac60111a017

Fageria, K., Baligar, C., \& Clark B. (2002). Micronutrients in crop production. Advances in Agronomy, 77, 185-267. https://doi.org/ 10.1016/S0065-2113(02)77015-6

Faver, L., Gerik, J., Thaxton, M., \& El-Zik M. (1996). Late season water stress in cotton: II. Leaf gas exchange and assimilation capacity. Crop Science, 36(4), 922-928. https://doi.org/10.2135/cropsci1996.0011183 X003600040018x

Flexas, J., \& Medrano, H. (2002). Drought-inhibition of photosynthesis in C3 plant: stomatal and non-stomatal limitation revisited. Annals of Botany, 89(2), 183-189. https://doi.org/10.1093/aob/mcf027

Grimes, D.W., \& El-zik, K.M. (1990). Cotton. In: Stewart, B.A., Dr. Nielsen (Eds.), Irrigation of Agricultural Crops-Agronomy Monograph, No: 30, p.741-748. ASA-CSSA-SSSA, 677 South Segoe Road, Madison, WI 53711, USA.

Guerfel, M., Baccouri, O., Boujnah, D., Chaibi, W., \& Zarrouk, M. (2009). Impacts of water stress on gas exchange, water relations, chlorophyll content and leaf structure in the two main Tunisian olive (Olea europaea L.) cultivars. Scientia Horticulturae, 119(3), 257-263. https://doi.org/ 10.1016/j.scienta.2008.08.006

Hare, P.D., \& Cress, W.A. (1997). Metabolic implications of stress-induced proline accumulation in plants. Plant Growth Regulation, 21, 79-102. https://doi.org/10.1023/A:1005703923347

Havlin, L., Beaton, D., Tisdale, L., \& Nelson, L. (2004). Soil fertility and fertilizers. An introduction to nutrient management. Prentice Hall: Upper Saddle River. London, 124: 406-425.

Hsu S.Y., Hsu, T., \& Kao, C.H. (2003). The effect of polyethylene glycol on proline accumulation in rice leaves. Biologia Plantarum, 46, 73-77. https://doi.org/10.1023/A:1022362117395

Kalefetoğlu, T., \& Ekmekçi, Y., (2005). The effect of drought on plants and tolerance mechanisms. Journal of Science, 18(4), 723-740

Kerepesi, I., \& Galiba, G. (2000). Osmotic and Salt Stress-Induced Alteration in Soluble Carbohydrate Content in Wheat Seedlings. Crop science, 40(2), 482487. https://doi.org/10.2135/cropsci2000.402482x

Kim, J., Mahe, A., Brangeon, J., \& Prioul, J. (2000). A maize vacuolar invertase, IVR2, is induced by water stress. Organ/tissue specificity and diurnal modulation of expression. Plant Physiology, 124, 71-84. https://doi.org/10.1104/pp.124.1.71 
Kishore, K.P.B., Sangam, S., Amrutha, R.N., Laxmi, P.S., Naidu, K.R., Rao K.R.S.S., ..... \& Sreenivasulu, N. (2005). Regulation of proline biosynthesis, degradation, uptake and transport in higher plants: its implications in plant growth andabiotic stress tolerance. Current Science, 88(3), 424-438.

Lichtenthaler, H.K. (1987). Pigments of photosynthetic biomembranes and carotenoids:. Methods in enzimology, 148, 350-382. https://doi.org/ 10.1016/0076-6879(87)48036-1

Marschner, H. (1995). Mineral nutrition of higher plants. 2nd edn. Academic Press, New York, pp. 889.

Mengel, K., \& Arneke, W. (1982). Effect of potassium on the water potential, the pressure potential, the osmotic potential and cell elongation in leaves of Phaseolus vulgaris. Physiologia Plantarum, 54(4), 402-408. https://doi.org/10.1111/j.1399-3054.1982.tb00699.x

Mirjahanmardi, H., \& Ehsanzadeh, P. (2016). Iron supplement ameliorates drought-induced alterations in physiological attributes of fennel (Foeniculum vulgare). Nutrient Cycling in Agroecosystems, 106, 61-76. https://doi.org/10.1007/s10705-016-9789-7

Moustakas, M., Sperdouli, I., Kouna, T., Antonopoulou, C.I., \& Therios, I. (2011). Exogenous proline induces soluble sugar accumulation and alleviates drought stress effects on photosystem II functioning of Arabidopsis thaliana leaves. Plant Growth Regulation, 65, 315-325. https://doi.org/10.1007/s10725-011-9604-z

Nikolaeva, K., Maevskaya, N., Shugaev, G., \& Bukhov, G. (2010). Effect of Drought on Chlorophyll Content and Antioxidant Enzyme Activities in Leaves of Three Wheat Cultivars Varying in Productivity. Russian Journal of Plant Physiology, 57, 87-95. https://doi.org/10.1134/ $\underline{\mathrm{S} 1021443710010127}$

Özturk, L., \& Demir, Y. (2002). In vivo and in vitro protective role of proline. Plant Growth Regulation, 38, 259-264. https://doi.org/10.1023/ A:1021579713832

Özüdoğru, T. (2019). Agricultural Products Report: Cotton. Institute of agricultural economics and policy development, pages 1-4.

Parida, K., Dagaonkar, S., Phalak, S., Umalkar, V., \& Aurangabadkar, P. (2007). Alterations in photosynthetic pigments, protein and osmotic components in cotton genotypes subjected to short-term drought stress followed by recovery. Plant Biotechnology Reports, 1, 37-48. https://doi.org/10.1007/s11816-006-0004-1

Pelleschi, S., Rocher, P., \& Prioul, L. (1997). Effect of water restriction on carbonhydrate metabolism and photosynthesis in mature maize leaves. Plant Cell and Environment, 20, 493-503. https://doi.org/ 10.1046/j.1365-3040.1997.d01-89.x

Pettigrew, W.T., Molin, W.T., \& Stetina, S.R. (2009). Impact of varying planting dates and tillage systems on cotton growth and lint yield production. Agronomy Journal, 101, 1131-1138. https://doi.org/10.2134/ agronj2009.0073

Peynircioğlu, C. (2014). Kuraklik stresine dayanikli pamuk (Gossypium hirsutum L.) çeşit islahinda kullanilacak pamuk genotiplerinin belirlenmesi (Yüksek lisans tezi). Adnan Menderes Üniversitesi, Aydın, Türkiye.

Rahman, H., Malik, S.A., \& Saleem, M. (2004). Heat Tolerance of Upland Cotton During the Fruiting Stage Evaluated Using Cellular Membrane Thermostability. Field Crops Research, 85,149-158. https://doi.org/ 10.1016/S0378-4290(03)00159-X

Reddy, R., Kakani, G., Zhao, D., Koti S., \& Gao, W. (2004). Interactive Effects of Ultraviolet-B Radiation and Temperature on Cotton Physiology, Growth, Development and Hyperspectral Reflectance. Photochemistry and Photobiology, 79, 416-427. https://doi.org/10.1111/j.17511097.2004.tb00029.x

Rhodes, D., \& Hanson A.D. (1993). Quaternary ammonium and tertiary sulfonium compounds in higher-plants. Annual Review of Plant Physiology and Plant Molecular Biology, 44, 357-384. https://doi.org/10.1146/annurev.pp.44.060193.002041

Salvucci, E., \& Crafts-Brandner, J. (2004). Inhibition of Photosynthesis by Heat Stress: The Activation State of Rubisco as a Limiting Factor in Photosynthesis. Physiologia Plantarum, 120,179-186. https://doi.org/10.1111/i.0031-9317.2004.0173.x

Samarah, N., Mullen, R., \& Cianzio, S. (2004). Size distribution and mineral nutrients of soybean seeds in response to drought stress. Journal of Plant Nutrition, 27, 815-835. https:// doi.org/10.1081/PLN-120030673

Sánchez, J., De Andrés, F., Tenorio, L., \& Ayerbe, L. (2004). Growth of epicotyls, turgor maintenance and osmotic adjustment in pea plants (Pisum sativum L.) subjected to water stress. Field Crops Research, 86, 8190. https:// doi.org/10.1016/S0378-4290(03)00121-7

Serraj, R., \& Sinclair, T.R. (2000). Osmolyte accumulation: can it really help increase crop yield under drought conditions? Plant, Cell and Environment, 25,333-341. https://doi.org/10.1046/j.13653040.2002.00754.x
Shafaqat, A., Shengguan, C., Fanrong Z., Boyin, Q., \& Guoping, Z. (2012). Effect Of Salınıty And Hexavalent Chromıum Stresses On Uptake And Accumulation Of Mineral Elements In Barley Genotypes Differing In Salt Tolerance. Journal of Plant Nutrion, 35, 827-839. https://doi.org/10.1080/01904167.2012.663438

Soil Survey Laboratory Methods Manual. (2004). Soil Survey Investigation Report United States Department of Agriculture Natural Resources Conservation Sevice No:42. Version 4.0 November.

Srinivas, V., \& Balasubramanian, D. (1995). Proline is a protein-compatible hydrotrope. Langmuir, 11: 2830-2833. https://doi.org/10.1021/ $\underline{\text { la00007a077 }}$

Taş, İ., \& Kırnak H. (2011). Drip irrigation method of Sanliurfa Pepper irrigated (Capsicum annum L.) Irrigation Program. Gaziosmanpaşa University Journal of agricultural, 28(1), 103-112.

Thimmanaik, S., Kumar, G., Kumari, J., Suryanarayana, N., \& Sudhakar, C. (2002). Photosynthesis and the enzymes of photosynthetic carbon reduction cycle in mulbery during water stres and recovery. Photosynthetica, 40, 233-236.

Ullah, I.R. (2008). Genotypic variation for drought tolerance in cotton (Gossypium hirsutum L.): Leaf gas exchange and productivity. Flora, 203, 105-115. https://doi.org/10.1016/j.flora.2007.12.001

USDA, (2019). Cotton World Markets and Trade, World Production, Markets and Trade Reports, https://www.fas.usda.gov/ data_analysis/scheduled-reports-2019.

Verbruggen, N., \& Hermans, C. (2008). Proline accumulation in plants: a review. Amino acids, 35, 753-759.

Wu, J., Wang, Y., \& Zhu, C. (2011). Overexpression of a cotton cyclophilin gene in transgenic tobacco plants confer dual tolerance to salt stres and Pseudomanas syringae pv. tabacci infection. Plant Physiology, 12, 79-61. https://doi.org/10.1016/i.plaphy.2011.09.001

Zali, G.A., \& Ehsanzadeh, P. (2018). Exogenous proline improves osmoregulation, physiological functions, essential oil, and seed yield of fennel. Industrial Crops \& Products, 111,133-140.https://doi.org/ 10.1016/j.indcrop.2017.10.020 